\title{
Evaluation of in vitro biological potential of plant species Sebastiania corniculata (Euphorbiaceae)
}

\author{
Isabelle Souza de Mélo Silva ${ }^{\text {* }}$, Raíssa Fernanda Evangelista Pires dos Santos ${ }^{2}$, Andriele Mendonça Barbosa ${ }^{1}$, \\ Klebson Silva Santos ', Mariene Ribeiro Amorim ', Flavia Manuella Ribeiro de Mendonça ', Ingridy Viana Lucena ', \\ Thiane de Vasconcellos Costa Melo ${ }^{2}$, Genilson Sarmento Lins Júnior ${ }^{2}$, Patricia de Albuquerque Sarmento ${ }^{2}$, \\ Francine Ferreira Padilha ${ }^{1}$, Maria Lysete de Assis Bastos ${ }^{2}$
}

From 5th Congress of the Brazilian Biotechnology Society (SBBIOTEC)

Florianópolis, Brazil. 10-14 November 2013

\section{Background}

Medicinal plants with antimicrobial properties built into the problem of multidrug deserve investment in research, by guiding the discovery of herbal medicine effective against emerging pathogens and related bacterial and fungal infection. Brazil has a great biodiversity of plants, which are popularly used for medicinal form. Vegetables have been widely used in health care due to its medicinal properties, such as antibacterial, antifungal and immunomodulatory activities [1]. Species of the family Euphorbiaceae are popularly used against diseases of viral, antimicrobial, anti-inflammatory, antiulcer, antihypertensive, muscle relaxant [2], including Sebastiania macrocarpa, Sebastiania hispida, Sebastiania commersoniana. However, works that related biological potential of Sebastiania corniculata species are scarce. Through this, the objective of this study was to evaluate the antimicrobial activity and toxicity of Sebastiania corniculata, guanxuma-de-chifre, popularly used as antidiarrheal, antibacterial and elimination of kidney stones [3].

\section{Methods}

Experimental in vitro study, was conducted at the Laboratory of Wound Care at Federal University of Alagoas. Were evaluated two fractions of the species Sebastiania corniculata extract, $\mathrm{X}_{\mathrm{A}}$ and $\mathrm{X}_{\mathrm{E}}$. 14 microorganisms were used, standardized between bacteria and fungi which were distributed by American Type Cell Collection. Antimicrobial activity was determined by microbial sensitivity tests,

'Instituto de Tecnologia e Pesquisa, Universidade Tiradentes - Av. Murilo

Dantas, 300, Farolândia - Aracaju, Sergipe, CEP 49032-490, Brazil

Full list of author information is available at the end of the article the method of disk diffusion (DD) and the method of broth microdilution for determination of minimum inhibitory concentration (MIC). All extracts were tested against Artemia salina Leach. For the study of cell viability, only the XA extract was tested.

\section{Results and conclusions}

The extracts showed moderately active for Staphylococcus aureus and Pseudomonas aeruginosa in the DD test (percentage inhibition $>28.6$ to $<51.38$ ), confirmed by the results of CIM. The extract $X_{A}$ is the fraction of the best antimicrobial potention, inhibiting the growth of $P$. aeruginosa lineage, concentration of 1000 to $125 \mu \mathrm{g}$ $\mathrm{mL}^{-1}$ by the result of the MIC. These results corroborate previous studies since species of the family Euphorbiacea [3], Heterocalyx croton and Euphorbia hirta [4], Palidullus croton and Croton ericoides, that also showed antimicrobial activities against these organisms [4]. Was identified the absence of toxicity in all samples, since the percentage of mortality was $\leq 30 \%$. This finding dismissed the realization of the quantitative assay. All extracts showed inactive against fungi tested, because it inhibited their growth. The low activity and/or the absence of antifungal activity may be due to the plant extracts tested did not damaged the membrane permeability to allow fungal cell. The evaluation of cytotoxicity by MTT, $\mathrm{X}_{\mathrm{A}}$ extract showed significant cytotoxicity $(\mathrm{p}<0.0001)$. These results cooperates with MTT describes a study significantly increased compared to the antitumour agent 5-fluorouracil [5]. In vitro studies are the basis for further research of technological advancement involving the use of $S$. corniculata for therapeutic purposes, including as antimicrobial. 


\section{Acknowledgements}

Brazilian Ministry of Science and Technology, Federal University of Alagoas, Center for Information Technology (CIT-PROPEP), Research Laboratory of Wound Care, Laboratory of Biomaterials, Tiradentes University.

\section{Authors' details}

'Instituto de Tecnologia e Pesquisa, Universidade Tiradentes - Av. Murilo Dantas, 300, Farolândia - Aracaju, Sergipe, CEP 49032-490, Brazil. Laboratório de Pesquisa em Tratamento de Feridas, Universidade Federal de Alagoas, Campus A. C. Simões - Av. Lourival Melo Mota, s/n, Cidade Universitária Maceió, Alagoas, CEP 57072-900, Brazil.

Published: 1 October 2014

\section{References}

1. Balbino CA, Pereira LM, Curi R: Mechanisms involved in wound healing: a review. Brazilian Journal of Pharmaceutical Sciences 2005, 41(1):27-51.

2. Bertucci A, Olivaro C, Silva PA, Ramos D, Cerdeiras MP, Vázquez A: Initial antimicrobial activity studies of plants of the riverside forests of the southern Uruguay River. Revista Brasileira de Farmacognosia 2009, 19(1A):20-25.

3. Lima MAA, Lima JQ, Arriaga AMC, Andrade-Neto M, Santiago GMP, Bezerra BP, Fereira YS, Veras HNH, Braz-Filho R: Chemical constituents of Sebastiania macrocarpa Muell. Arg. (Euphorbiaceae). Chemistry New 2009, 32(2)

4. Vunda SLL, Sauter IP, Cibulski SP, Roehe PM, Bordignon SAL, Rott MB, Apel MAA, Poser GL: Chemical composition and amoebicidal activity of Croton pallidulus, Croton ericoides, and Croton isabelli (Euphorbiaceae) essential oils. Parasitol Res 2012, 111(3):961-66.

5. Shu X, Yu L, Tang Y, Zhang L, Ding A, Dan L, Duan J, Shen X: Bioassay-guided separation of the proinflammatory constituents from the roots of Euphorbia kansui. J Nat Med 2010, 64(1):98-103.

doi:10.1186/1753-6561-8-S4-P40

Cite this article as: Mélo Silva et al:: Evaluation of in vitro biological potential of plant species Sebastiania corniculata (Euphorbiaceae). BMC Proceedings 2014 8(Suppl 4):P40.

\section{Submit your next manuscript to BioMed Central and take full advantage of:}

- Convenient online submission

- Thorough peer review

- No space constraints or color figure charges

- Immediate publication on acceptance

- Inclusion in PubMed, CAS, Scopus and Google Scholar

- Research which is freely available for redistribution

Submit your manuscript at www.biomedcentral.com/submit 